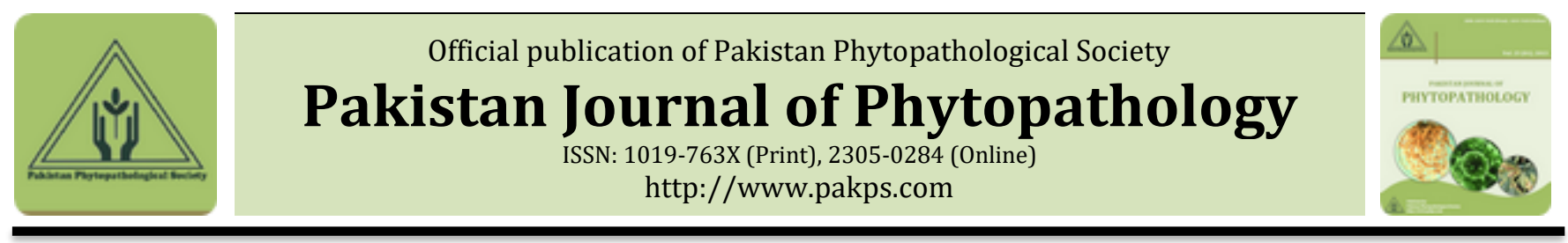

\title{
EVALUATION OF GROUNDNUT (ARACHIS HYPOGEA L.) MUTANT GENOTYPES FOR RESISTANCE AGAINST MAJOR DISEASES OF GROUNDNUT
}

\author{
Frederick Kankam*, Kwame Y. Kojo, Isaac K. Addai \\ Department of Agronomy, Faculty of Agriculture, University for Development Studies, P. O. Box TL1882, \\ Nyankpala Campus, Tamale, Ghana
}

A B S T R A C T

\begin{abstract}
A field experiment was conducted at the Farming for the Future field of the Faculty of Agriculture, Nyankpala campus of the University for Development Studies, UDS, to evaluate groundnut genotypes for resistance against three major groundnut diseases namely early leaf spot (ELS) Cercospora arachidicola, late leaf spot (LLS) Phaeoisariopsis personata and groundnut rosette disease under natural infestation. The experiment was consisted of 6 treatments including four groundnut genotypes (150 Gy, $200 \mathrm{~Gy}, 250 \mathrm{~Gy}$, and $300 \mathrm{~Gy}$ ) and two standard checks (Chinese and Nkatie SARI varieties). The treatments were replicated three times in a randomized complete block design. Data were collected on ELS and LLS severity using a modified nine point scale (1-9), while rosette disease score was assessed using a 1-5 disease rating scale. Yield of groundnut and resistance level were also determined at 85 DAP. The results revealed that, mutant genotypes $250 \mathrm{~Gy}$ and $200 \mathrm{~Gy}$ had the highest yield compared with the other genotypes. The $250 \mathrm{~Gy}$ was found to be resistant against all the three major groundnut diseases studied, while the $150 \mathrm{~Gy}, 200 \mathrm{~Gy}$, 300 Gy and the two controls exhibited moderate resistance. Genotype 200 Gy demonstrated resistance against the rosette disease, while the 150 Gy and 300 Gy showed moderate resistance and the two controls were susceptible to groundnut rosette disease. The ELS and LLS diseases correlated negatively with pods per plant and grain yield, respectively, while the rosette disease showed negative correlation with both pods per plant and grain yield. Genotype 250 Gy was resistant against the three major groundnut diseases, and can be further used in future analytical breeding studies to identify and assess specific genes responsible for the resistance, at molecular level for advanced improvement.
\end{abstract}

Keywords: Mutagenesis, early leaf spot, late leaf spot, groundnut rosette disease, incidence.

\section{INTRODUCTION}

Groundnut (Arachis hypogea L.) is a leguminous crop which is now grown in both the tropical and subtropical countries as oil seed (Ephrem, 2015). It is cultivated on subsistence and commercial bases for food and industrial purposes (Thakur et al., 2013; Mohammed et al., 2018). The general productivity of groundnut in Africa is comparatively low, compare to that of America due to a number of constraints such as biological,

Submitted: March 03, 2020

Revised: June 16, 2020

Accepted for Publication: June 19, 2020

* Corresponding Author:

Email: fkankam@uds.edu.gh

(C) 2017 Pak. J. Phytopathol. All rights reserved. undulating climate, socio-economic factors, pests and diseases (Zongo et al., 2019). The average output of groundnut in Africa (902.6 kg/ha) is very low comparative to the American output of $33381.4 \mathrm{~kg} / \mathrm{ha}$ (FAOSTAT, 2018). The average yield of groundnut in Africa is about $1 / 4$ of that of the America's and about $1 / 2$ of the yield of Asia due to low mechanization, pressure of pest and diseases and low yielding varieties among others (Desmae and Sones, 2017). Groundnut is considered as the most valuable crop among legumes, grown in northern Ghana because of its economic, dietary and industrial advantages (Sugri, 2020).

Mohammed et al. (2019) reported that, the combination of leaf spot, rosette disease and drought can lead to yield loss of $100 \%$ in groundnut. Number of groundnut 
germplasm has been reported having various degree of resistance to the early leaf spot, late leaf spot and rosette disease of groundnut, however, knowledge about resistance level exhibited by the germplasm is not sufficient (Mohammed et al., 2018). The early leaf spot has symptoms of brown to reddish brown colour usually surrounded by yellow halo on the upper surface of the leaf while late leaf spot has symptoms of dark brown to black spots, normally with no yellow halo on the lower surface of the leaf (Desmae and Sones, 2017). Total resistance to the early and late leaf spots fungi has not yet been identified (Zongo et al., 2019).

The groundnut rosette virus disease is native to SubSaharan Africa and its endemic has been observed in Burkina Faso, Ghana, Nigeria, Malawi, Mozambique, Mali, Niger Republic, Uganda, Kenya and Tanzania (Thuo et al., 2014). Kayondo et al. (2014) reported rosette associated annual yield loss of US\$ 156 million in SubSahara Africa, according to the estimation of the International Crop Research Institute for Semi-Arid Tropics. It occurs in an alarming rate annually and negatively affects rural economic growth in Sub-Saharan Africa (Mukoye and Mabele, 2019). The groundnut rosette disease is caused by three individual viral components: groundnut rosette virus (GRV), satellite RNA (SAT RNA) and groundnut rosette assistor virus (GRAV) (Kayondo et al., 2014) and transmitted by the Aphis craccivora Koch. It has two types of symptoms, the chlorotic rosette that has been observed in Sub-Sahara Africa since introduction of groundnut into this region and the green rosette form has only been present in West African nations (Mugisa et al., 2016). A third symptom of mosaic rosette has also been observed in the areas of East and Southern Africa (Mabele et al., 2018). The chlorotic rosette have bright yellow colored leaves with a small spot of green and the green rosette have light green to dark green mosaic with leaf margins curled downwards (Desmae and Sones, 2017).

The most important problem encountered in the groundnut cultivation areas in Northern Ghana is the incidence of diseases, notably the early and late leaf spots which are caused by Cercospora arachidicola and Phaeoisariopsis personata (Frimpong et al., 2006b). These two leaf spots diseases are key biological factors against groundnut production in Northern Ghana (Alidu et al., 2019). The most common and commercial variety, (Chinese) grown in the Guinea savannah of Ghana is highly vulnerable to these diseases (Alidu et al., 2019).
The application of induced mutation has led to the generation of new and beneficial modifications of characteristics features of plants including high yielding and disease resistance qualities. Gamma rays, a physical mutagen from the ionizing radiation group, used in mutation breeding can have direct actions on the molecular composition of the cell (Gaswanto et al., 2016). Gamma rays also act on free moving radicals transported by water, which can negatively impact or transform fundamental cellular constituents of plant and several studies have shown that differential influences from gamma radiations can alter structural morphology and physio-chemical characteristics of plants (Kim et al., 2004).

Lack of resistant variety to these three major diseases encouraged the continuous use of chemicals to control it (Khan et al., 2013). In groundnut production area like northern Ghana, groundnut is extensively cultivated by peasant farmers who are financially weak to afford the chemical control method during the growing season (Adu-Dapaah et al., 2004). The use of chemicals to control plant pathogens causes water and soil pollutions as well as destruction of beneficial soil microorganisms (Rani et al., 2017). Though chemical control has proven to be effective for increasing yield, it can potentially cause harm to human and environment through residues (Al-Ahmadi, 2019). The severity of these diseases sometimes calls for some farmers in the rural settings of northern Ghana to use some un-approved and highly hazardous agrochemicals of which they have only little or no knowledge about and also lack entirely the requisite training in relation to mode of application and safety measures. Hence, one of the most appropriate alternatives to combat diseases of crop plants is the use of biologically engineered cultivars having resistance (Rani et al., 2019). According to Desmae and Sones (2017) the best approach to overcome leaf spots disease of groundnut is the use of resistance varieties.

A number of resistant lines of groundnut have been found in several studies (Monyo and Varshney, 2016). Muduli and Misra (2007) also reported that, the exposure of genetic material such as seed, callus and pollen to irradiations facilitate the likelihood for obtaining peculiar genetic material, which can generate the variations of quantitative and qualitative crops heritable features. This research was particularly aimed at determining groundnut mutant genotypes resistant to major groundnut diseases (the early leaf spot, late leaf 
spot and the rosette disease) under natural field infestation in order to minimize yield losses caused by these diseases.

\section{MATERIALS AND METHODS}

Experiment Site: Field experiment was carried out during the 2018/2019 cropping season, from June to October at the University for Development Studies, Faculty of Agriculture's Faming for the Future field at Nyankpala in the Tolon district of the northern region of Ghana, about 20 kilometers South-West of Tamale. Nyankpala is located between $9^{\circ} 24^{\prime} 0^{\prime \prime}$ North and $0^{\circ} 59^{\prime}$ $0 "$ "West and found in the guinea savannah agroecological zone of Ghana. The area experiences a monomodal rainfall, with an annual rainfall of about 1000-1200 mm dispensed evenly from April to November. It has a uniform temperature distribution with the average minimum and maximum of $21 \mathrm{C}^{\circ}$ and $32 \mathrm{C}^{\circ}$ respectively per month (SARI Annual Report, 2012). The soil is sandy-loam, moderately drained, contains no hard mass and formed from Voltarian rock which is described as Nyankpala series (SARI Annual Report, 2012).

Sources of groundnut genotypes: The groundnut

$$
\text { PDI }=\frac{\text { Number of plants showing disease symptom }}{\text { Total number of plants per plot }} \times 100
$$

Early and late leaf spots severity: Early leaf spot and where a score of 1 was rated as highly resistant (HR), 2 Late leaf spot disease severity scorings were done at 45 and 85 days after planting (DAP) using a modified 9point scale (Subrahmanyam et al., 1995) (Table 1), to 4 as resistant (R), 5 and 6 as moderately resistant (MR), 7 and 8 as susceptible and 9 as highly susceptible (HS).

Table 1 Modified 9-point scale used for field screening of groundnut genotypes for resistance to ELS and LLS

\begin{tabular}{|c|c|c|}
\hline $\begin{array}{l}\text { Disease } \\
\text { score }\end{array}$ & Description of disease & $\begin{array}{l}\text { Severity } \\
(\%)\end{array}$ \\
\hline 1 & No disease & 0 \\
\hline 2 & Lesions present largely on lower leaves; no defoliation. & $1-5$ \\
\hline 3 & $\begin{array}{l}\text { Lesions present largely on lower leaves, very few on middle leaves; defoliation of some } \\
\text { leaflets evident on lower leaves. }\end{array}$ & $6-10$ \\
\hline 4 & $\begin{array}{l}\text { Lesions on lower and middle leaves but severe on lower leaves; defoliation of some Leaflets } \\
\text { evident on lower leaves. }\end{array}$ & $11-20$ \\
\hline 5 & Lesions present on all lower and middle Leaves; over $50 \%$ defoliation of lower leaves. & $21-30$ \\
\hline 6 & $\begin{array}{l}\text { Severe lesions on lower and middle leaves; lesions present but less severe on top leaves; } \\
\text { extensive defoliation of lower leaves; defoliation of some leaflet evident on middle Leaves. }\end{array}$ & $31-40$ \\
\hline 7 & $\begin{array}{l}\text { Lesions on all leaves but less severe on top leaves; defoliation of all lower and some middle } \\
\text { leaves }\end{array}$ & $41-60$ \\
\hline 8 & $\begin{array}{l}\text { Defoliation of all lower and middle leaves; severe lesions on top leaves; some defoliation of } \\
\text { top leaves evident. }\end{array}$ & $61-80$ \\
\hline 9 & $\begin{array}{l}\text { Almost all leaves defoliated, leaving bare Stems, some leaflets may remain, but show severe } \\
\text { leaf spots. }\end{array}$ & $80+$ \\
\hline
\end{tabular}

(Subrahmanyam et al., 1995; Wilber, 2014) 
Rosette disease severity: Groundnut rosette disease (GRD) severity was assessed by scoring at 85 days after planting (DAP) using a 1-5 disease rating scale (Pande et al., 1997;
Olorunju et al., 2001) (Table 2). Where $0=$ Highly resistant (HR), 1 = Resistant (R), 2 = Moderately resistant (MR), 3 = Susceptible (S) and 4 = Highly susceptible (HS).

Table 2: A 1-5 disease rating scale for scoring the severity of the rosette disease of groundnut

\begin{tabular}{cl}
\hline Scale & Description of disease \\
\hline 0 & No visible symptoms on leaves \\
\hline 1 & Rosette symptoms on 1-20\% leaves, but no obvious stunting \\
\hline 2 & Rosette symptoms on $21-50 \%$ leaves with stunting \\
\hline 3 & Severe symptoms on $51-70 \%$ leaves with stunting \\
\hline 4 & Severe symptoms on 71 to $100 \%$ leaves with stunting \\
\hline
\end{tabular}

(Pande et al., 1997; Olorunju et al., 2001)

Number of pods per plant: A sample of five plants was selected at random from each plot at harvest and their pods were plucked together, counted and the average was taken.

\section{Formula $=\frac{\text { Sum of pods from selected plants }}{\text { Number of selected plants }}$}

Total grain yield: Pods were plucked from all the groundnut plants per each plot. The pods were sun-dried for four days and weighed in kilograms. The weight in kilogram per plot was further extrapolated to kilogram per hectare scale, to obtain the average grain yield per hectare.

\section{DATA ANALYSIS}

All data collected were subjected to analysis of variance (ANOVA). Genstat (18 $8^{\text {th }}$ edition) statistical package was used in the analysis. Means were separated using the Least Significant Difference test (LSD) at 5\% probability level.

RESULTS

Disease incidence: The incidences of early and late leaf spots diseases were significantly different $(P<0.05)$. The 250 Gy recorded the least percentages of early and late leaf spots incidences (Figure 1). Rosette disease incidence was also significantly different $(P<0.05)$. The 200 Gy and 250 Gy recorded the least percentages and the controls (Chinese and the Nkatie SARI) gave the highest percentages. There were no significant differences in the percentages of ELS, LLS and rosette incidences among the other genotypes. However, the percentages of rosette incidence recorded by these genotypes were significantly different from that of the 200 Gy and 250 Gy (Figure 1).

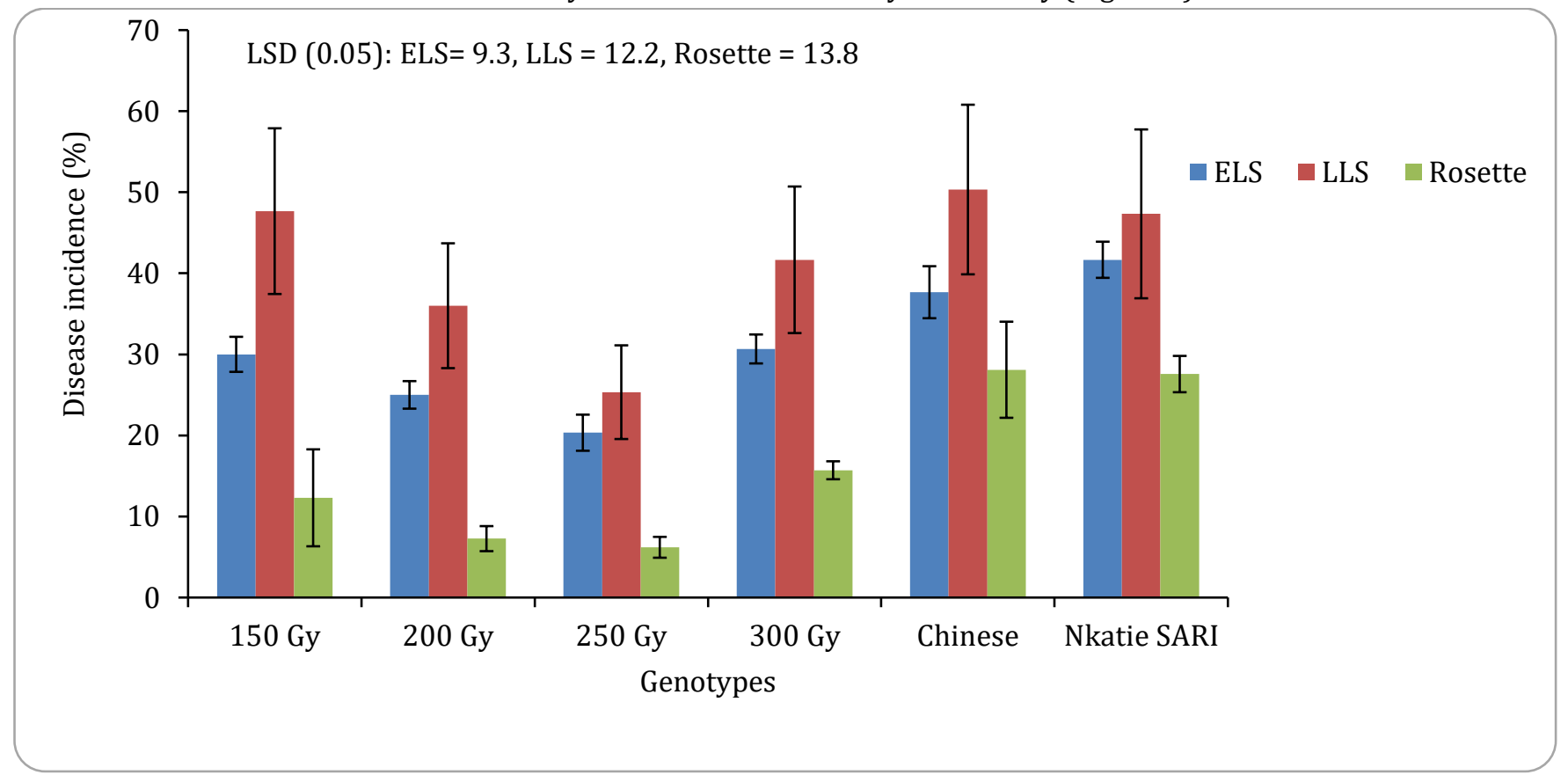

Figure 1. Reactions of groundnut mutant genotypes to major diseases of the crop. Error bars represent standard error of means (SEM). 
Severity of major groundnut diseases: The severity of the ELS disease among the mutant genotypes was not significantly different $(P>0.05)$. However, the 250 Gy recorded the least mean severity score, which was significantly different from the other genotypes and the two controls (Chinese and Nkatie SARI). The severity of the LLS showed a significant difference $(P<0.05)$ among the groundnut genotypes. Genotype 250 Gy was resistant against the ELS and LLS diseases, whilst the other genotypes and the controls were moderately resistant (Table 3).

Table 3: Disease severity for ELS, LLS and GRD for groundnut genotypes

\begin{tabular}{llll}
\hline Treatment & ELS & LLS & GRD \\
\hline $150 \mathrm{~Gy}$ & $4.6(\mathrm{MR})$ & $6.1(\mathrm{MR})$ & $2.2(\mathrm{MR})$ \\
$200 \mathrm{~Gy}$ & $4.9(\mathrm{MR})$ & $6.0(\mathrm{MR})$ & $1.4(\mathrm{R})$ \\
$250 \mathrm{~Gy}$ & $3.7(\mathrm{R})$ & $4.2(\mathrm{R})$ & $1.0(\mathrm{R})$ \\
$300 \mathrm{~Gy}$ & $4.5(\mathrm{MR})$ & $5.9(\mathrm{MR})$ & $2.0(\mathrm{MR})$ \\
Chinese & $5.1(\mathrm{MR})$ & $6.1(\mathrm{MR})$ & $3.1(\mathrm{~S})$ \\
Nkatie SARI & $5.2(\mathrm{MR})$ & $5.9(\mathrm{MR})$ & $2.6(\mathrm{~S})$ \\
LSD $(0.05)$ & 1.2 & 1.3 & 1.0 \\
CV $(\%)$ & 14.2 & 12.6 & 26.2 \\
\hline
\end{tabular}

Where: ELS Means Early leaf spot, LLS Means Late leaf spot and GRD Means Groundnut rosette disease. Resistance level with respect to the peak of diseases severities, where: $\mathrm{R}=$ Resistance, $\mathrm{MR}=$ Moderate Resistance, $\mathrm{S}=$ Susceptible, as defined in Table 1 and 2 for early and late leaf spot and rosette respectively.

Number of pods per plant: The incidence of diseases studied had a significant influence $(P<0.05)$ on the average number of pods per plant. Mutant genotype 250 Gy recorded more pods per plant while the $300 \mathrm{~Gy}$ recorded least number of pods per plants (Figure 2). The
There were significant differences $(P<0.05)$ in severity score for the rosette disease among the genotypes (Table 3). Mutant genotypes 250 Gy had the least rosette severity score. Mutant genotype 250 Gy was also significantly different $(P<0.05)$ compared with the genotypes $150 \mathrm{~Gy}$, 300 Gy and the two controls (Chinese and Nkatie SARI), except genotype $200 \mathrm{~Gy}$, in the mean disease severity score and the corresponding resistance level. Mutant genotypes 150 Gy, and 300 Gy were moderately resistant against rosette disease, whilst the Chinese and the Nkatie SARI were susceptible to groundnut rosette disease (Table 3).

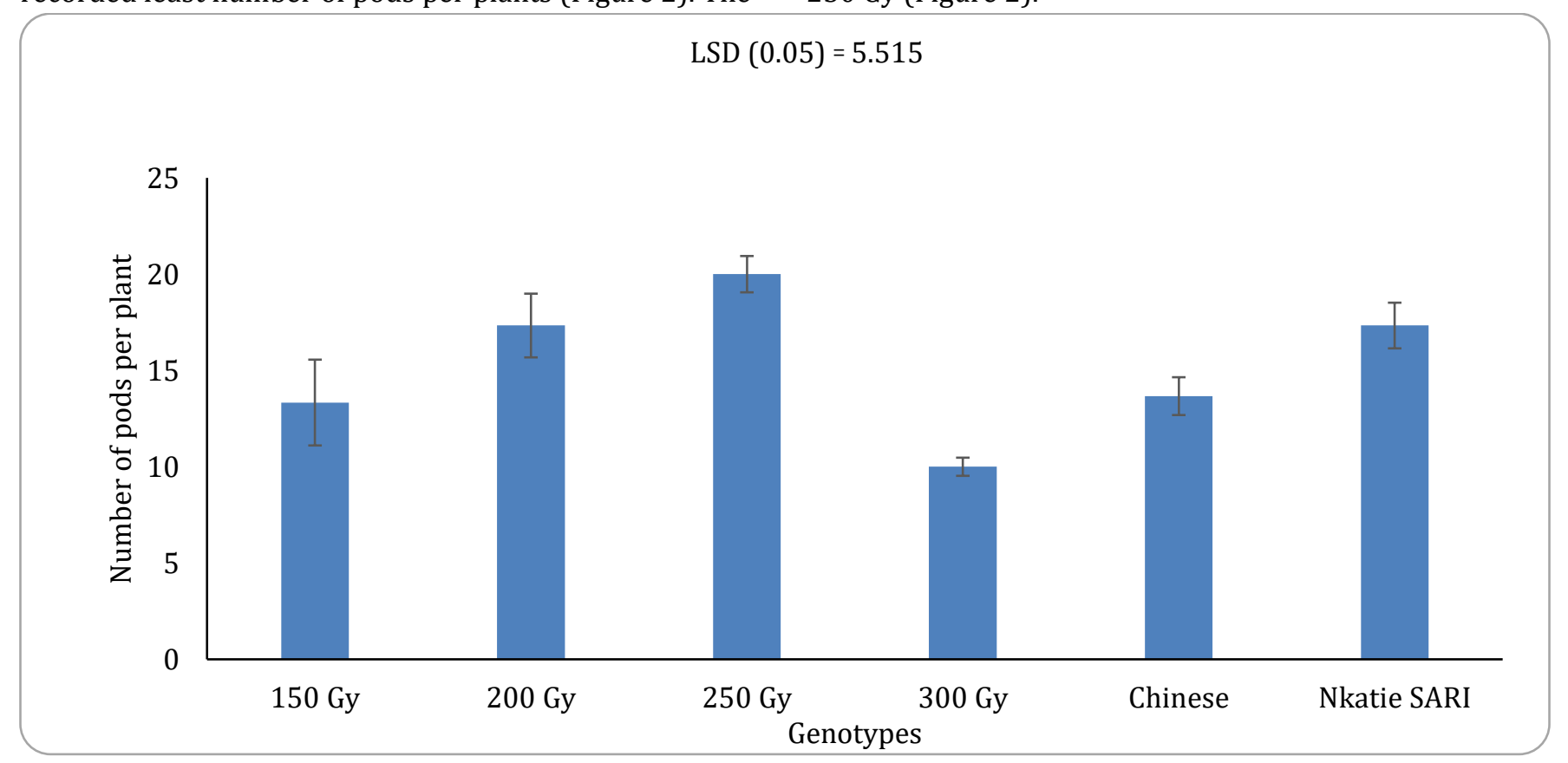

Figure 2. The influence of diseases incidences on groundnut pods per plant. Error bars represent standard error of means (SEM). 
spread of their symptoms were relatively low as compared to those of the controls. Mutant genotype 250 Gy was resistant to early leaf spot and late leaf spot disease compared with the other mutant genotypes, which showed moderate resistance. This might be possibly due to genetic factor, as these genotypes (200 Gy and 250 Gy) were exposed to different doses of gamma radiations, altered their genetic constitutions, given rise to high resistant capacities against the diseases.

The severity of the groundnut rosette disease was high on the field and the genotypes exhibited variable level of resistance from 45 to 85 days after planting (Table 3). For instance, mutant genotypes $200 \mathrm{~Gy}$ and the $250 \mathrm{~Gy}$ were resistant to the groundnut rosette virus disease. This conforms to earlier reports that, severely infected rosette groundnut plants became stunted in growth, assumed bushy appearance as a result of persistent reduced internodes lengths and shrink or malformed leaves (A'brook, 2007). Bwala et al. (2019) also reported that the Samnut-10, Samnut-21 and Samnut-22 genotypes of groundnut were resistant to the rosette virus disease(s) when screened for resistance. The 150 Gy and the 300 Gy were also moderately resistant (Table 3). Appiah et al. (2016) reported similar findings under a field trial in Ghana, where some groundnut cultivars showed moderately resistant to resistant response to rosette disease.

The study revealed that genotype 250 Gy recorded the highest number of pods per plant which was significantly different from all the other genotypes and the controls. The result is in conformity to that of Alidu et al. (2019) who reported that genotype F-Mix had a higher number of pods per plant than the already existing groundnut cultivars in Northern Ghana. Mutant genotype 300 Gy had the lowest pods per plant, which might be attributed to the influence of the dose of the radiation on the genes of that genotype. The decrease in pods per plant varied marginally among the genotypes based on the degree of the severity of the disease(s). This is in line with Waliyar et al. (2000) earlier report that, the defoliation by foliar diseases such as early and late leaf spots diseases distorts the leaf cells and disrupts the processes of photosynthesis leading to reduction in pod yield. Number of pods per plant also correlated negatively with the rosette and early leaf spot diseases, as shown in Table 4, which means the increase in early leaf spot and rosette disease severity lead to decrease in number of pods per plant.

The combined variable effects of the early leaf spot, late leaf spot and groundnut rosette diseases significantly influenced the total yield per hectare (Figure 3). Mutant genotype 250 Gy which was resistant against the three major groundnut diseases recorded the highest grain yield, followed by the 200 Gy which showed moderate resistance to ELS and LLS diseases. The Chinese and the Nkatie SARI varieties recorded low yields which might be attributed to inhibition of photosynthetic processes due to the intense reduction in leaf area and defoliation by the diseases. This is line with Singh and Shukla (2009) who reported a decrease in chlorophyll composition in disease affected plants. Most of the plants which were severely affected by the diseases did not produce pods. And this is consistent with earlier reports that, foliar diseases of groundnut such as rosette can cause an important yield loss in groundnut up to $100 \%$ (Dwivedi, et al., 2003). Both the groundnut rosette disease and the late leaf spot disease showed negative correlations with grain yield (Table 4). Thus, as severities of the groundnut rosette disease and late leaf spot disease increases, the grain yield decreases. The result is in agreement to that of Mohammed et al. (2018) who reported significant negative correlations between the late leaf spot, rosette disease and yield of groundnut. CONCLUSION

The mutant genotypes showed some levels of resistance against all the three major groundnut diseases. Mutant genotype 250 Gy was found to be resistant against all the three major diseases studied while genotype $150 \mathrm{~Gy}$ and 300 Gy showed moderate level of resistance. However, the 200 Gy was resistant to groundnut rosette disease. Mutant genotypes 150 Gy and 300 Gy were moderately resistant against the early leaf spot, late leaf spot and groundnut rosette disease and are likely to succumb to these diseases under high disease incidence. But the control (Chinese and Nkatie SARI) varieties were found to be susceptible to groundnut rosette virus disease. The correlation between late leaf spot and rosette diseases and yield parameters showed decrease in pods per plant and yield of groundnut as the severity of the disease increases. Mutant genotype 250 Gy can be used in further analytical breeding programs to identify and evaluate specific responsible genes at molecular level.

\section{REFERENCES}

A'Brook, J. 1964. The effect of planting date and spacing on the incidence of groundnut rosette disease and of the 
vector, Aphis craccivora Koch, at Mokwa, Northern Nigeria. Annals of Applied Biology, 54: 199-208.

Adu-Dapaah, H. K., J. Asibuo, O. Danquah, H. Asumadu, J. Haleegoah and B. Agyei. 2004. Farmer participation in groundnut rosette resistant varietal selection in Ghana. Proceedings for the 4th International Crop Science. Congress, Brisbane, Australia. p. 96.

Alidu, M. S., S. Abukari and M. Abudulai. 2019. Screening Groundnut (Arachis hypogeae) Genotypes for Resistance to Early and Late Leaf Spot Diseases. Journal of Experimental Agriculture International: 19.

Appiah, A. S., S. K. Offei, R. S. Tegg and C. R. Wilson. 2016. Varietal Response to Groundnut Rosette Disease and the First Report of Groundnut ring spot virus in Ghana. Plant Disease, 100: 946-952.

Desmae, H. and H. Sones. 2017. Groundnut cropping guide. Dwivedi, S., S. Gurtu, S. Chndra, H. Upadhyaya and S. Nigam. 2003. AFLP diversity among selected rosette resistant groundnut germplasm. International Arachis Newsletter: 21-23.

Food and Agricultural Organizations of the United Nations FAOSATAT. 2018. Statistical Data Base. Food and Agricultural Organizations of the United Nations: Rome, Italy.

Frimpong, A., F. K. Padi, J. Kombiok, A. B. Salifu and K. O. Marfo. 2006. Registration of 'Edorpo-Munikpa' Peanut. Crop Science, 46: 1396-1396.

Gaswanto, R., M. Syukur, B. S. Purwoko and S. H. Hidayat. 2016. Induced mutation by gamma rays irradiation to increase chilli resistance to begomovirus. AGRIVITA Journal of Agricultural Science, 38.

Guchi, E. 2015. Aflatoxin contamination in groundnut (Arachis hypogaea L.) caused by Aspergillus species in Ethiopia. Journal of applied \& environmental microbiology, 3: 11-19.

Isa Bwala, R., N. Alphonso Okechukwu and G. Victor Iorungwa. 2019. Screening of groundnut (Arachis hypogaea $\mathrm{lL}$.) genotypes for their resistance to rosette virus disease in southern guinea savanna of nigeria. International Journal of Agriculture Environment and Bioresearch, 04: 69-80.

Kayondo, S., P. Rubaihayo, B. Ntare, P. Gibson, R. Edema, A. Ozimati and D. Okello. 2014. Genetics of resistance to groundnut rosette virus disease. African crop science journal, 22: 21-30.

Khan, M. T., N. A. Khan, M. Bezabih, M. S. Qureshi and A. Rahman. 2012. The nutritional value of peanut hay
(Arachis hypogaea L.) as an alternate forage source for sheep. Tropical Animal Health and Production, 45: 849-853.

Kim, J.-H., M.-H. Baek, B. Y. Chung, S. G. Wi and J.-S. Kim. 2004. Alterations in the photosynthetic pigments and antioxidant machineries of red pepper (Capsicum annuum L.) seedlings from gammairradiated seeds. Journal of Plant Biology, 47: 314321.

Mabele, A. S. 2020. Occurrence, distribution and molecular diversity of groundnut rosette assistor virus causing groundnut rosette disease in western kenya.

Mohammed, K. E., E. E. Agoyi, T. L. Odong, B. Miesho, D. K. Okello, O. Giregon, P. R. Rubaihayo and P. Okori. 2019. Yield penalty associated with stacking resistance to late leaf spot, rosette diseases and drought stress in groundnut (Arachis hypogaea L.). Int. J. Adv. Res., 7 (6): 178-190.

Mohammed, K., E. Afutu, T. Odong, D. Okello, E. Nuwamanya, O. Grigon, P. Rubaihayo and P. Okori. 2018. Assessment of Groundnut (Arachis hypogaea L.) Genotypes for Yield and Resistance to Late Leaf Spot and Rosette Diseases. Journal of Experimental Agriculture International, 21: 1-13.

Monyo, E. S. and R. Varshney. 2016. Seven seasons of learning and engaging smallholder farmers in the drought-prone areas of sub-Saharan Africa and South Asia through Tropical Legumes, 2007-2014. ICRISAT.

Muduli, K. and R. Misra. 2007. Efficacy of mutagenic treatments in producing useful mutants in finger millet (Eleusine coracana Gaertn.). Indian Journal of Genetics and Plant Breeding, 67: 232-237.

Mugisa, I., J. Karungi, B. Akello, M. Ochwo-Ssemakula, M. Biruma, D. Okello and G. Otim. 2016. Determinants of groundnut rosette virus disease occurrence in Uganda. Crop Protection, 79: 117-123.

Mukoye, B. and A. S. Mabele. 2019. Genetic diversity of Groundnut rosette disease causal agents towards its management: A review. International Journal of Genetics and Genomics, 7: 12-17.

Ngegba, P. M., O. A. Enikuomehin, C. G. Afolabi, A. K. Akintokun, A. O. Egbontan and S. K. Kanneh. 2017. "Efficacy of plants extracts on cercospora leaf spot incidence and severity of groundnut (Arachis hypogaea $L$.) In-vivo. International Journal of Current Research, 9 (12): 63007-63013.

Nigam, S. N., R. D. V. J. Prasada Rao, P. Bhatnagar-Mathur 
and K. K. Sharma. 2012. Genetic Management of Virus Diseases in Peanut. Plant Breeding Reviews. John Wiley \& Sons, Inc., pp. 293-356.

Olorunju, P. E., B. R. Ntare, S. Pande and S. V. Reddy. 2001. Additional sources of resistance to groundnut rosette disease in groundnut germplasm and breeding lines. Annals of Applied Biology, 139: 259268.

Pande, S., P. Olorunju, A. Minigou, B. Ntare and F. Waliyar. 1997. Rosette disease of groundnut and its management in west and central Africa. Arachide Infos, 7: 13-17.

Rani, A., R. Singh, P. Kumar and G. Shukla. 2017. Pros and cons of fungicides: an overview. International journal of engineering sciences and research technology, 6: 112-117.

SARI. 2012. Savannah Agriculture Research Institute"s Annual Report.

Saud Al-Ahmadi, M. 2019. Pesticides, Anthropogenic Activities, and the Health of Our Environment Safety. Pesticides - Use and Misuse and Their Impact in the Environment. IntechOpen.

Singh, V. and K. Shukla. 2009. Effect of PRSV Infection on Pigment Content and Assimilation of Carbohydrate in Carica papaya L. Annals of Plant Protection Sciences, 17: 152-156.

Subrahmanyam, P., D. McDonald, F. Waliyar, L. Reddy, S. Nigam, R. Gibbons, V. R. Rao, A. Singh, S. Pande and P. Reddy. 1995. Screening methods and sources of resistance to rust and late leaf spot of groundnut. Information Bulletin no. 47. International Crops Research Institute for the Semi-Arid Tropics.

Sugri, I. 2020. Prevalence, Perception and Participatory Management of Aflatoxins in Groundnut with Emphasis on Northern Ghana. Acta Scientifci Nutritional Health, 4: 01-10.

Thakur, V. K., M. K. Thakur and R. K. Gupta. 2013. Rapid synthesis of graft copolymers from natural cellulose fibers. Carbohydrate polymers, 98: 820-828.

Thuo, M., A. A. Bell, B. E. Bravo-Ureta, M. A. Lachaud, D. K. Okello, E. N. Okoko, N. L. Kidula, C. M. Deom and N. Puppala. 2014. Effects of social network factors on information acquisition and adoption of improved groundnut varieties: the case of Uganda and Kenya. Agriculture and human values, 31: 339-353.

Waliyar, F., M. Adamou and A. Traoré. 2000. Rational Use of Fungicide Applications to Maximize Peanut Yield Under Foliar Disease Pressure in West Africa. Plant Disease, 84: 1203-1211.

Waliyar, F., P. Kumar, B. Ntare, E. Monyo, S. Nigam, A. Reddy, M. Osiru and A. Diallo. 2007. A century of research on groundnut rosette disease and its management. Information Bulletin no. 75.

Zongo, A., A. K. Konate, K. Koïta, M. Sawadogo, P. Sankara, B. R. Ntare and H. Desmae. 2019. Diallel Analysis of Early Leaf Spot (Cercospora arachidicola Hori) Disease Resistance in Groundnut. Agronomy, 9: 15.

\section{Contribution of Authors:}

Frederick Kankam

Kwame Y. Kojo

Isaac K. Addai
: Design research, manuscript write up.

: Conduct research and write up.

: Help in conducting research and write up. 